\title{
ZMIZ1 wt Allele
}

National Cancer Institute

\section{Source}

National Cancer Institute. ZMIZ1 wt Allele. NCI Thesaurus. Code C119667.

Human ZMIZ1 wild-type allele is located in the vicinity of 10q22.3 and is approximately $247 \mathrm{~kb}$ in length. This allele, which encodes zinc finger MIZ domain-containing protein 1 , is involved in the modulation of androgen receptor-dependent genes. 